Dreaming the Graphic Novel 



\section{Dreaming the Graphic Novel}

$\bullet \bullet \bullet \bullet \bullet \bullet \bullet \bullet \bullet \bullet \bullet \bullet \bullet \bullet \bullet \bullet \bullet \bullet \bullet \bullet \bullet \bullet \bullet \bullet \bullet \bullet$ The Novelization of Comics

PAUL WILLIAMS

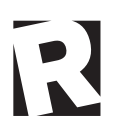

Rutgers University Press

New Brunswick, Camden, and Newark, New Jersey, and London 
Library of Congress Cataloging-in-Publication Data

Names: Williams, Paul, 1979- author.

Title: The novelization of comics : dreaming of the graphic novel in the long 1970s / Paul Williams.

Description: New Brunswick : Rutgers University Press, [2020] | Includes bibliographical references.

Identifiers: LCCN 2019007532 | ISBN 9781978805064 (pbk.)

Subjects: LCSH: Graphic novels-History and criticism. | Comic books, strips, etc.-History and criticism.

Classification: LCC PN6710.W55 2020 | DDC 741.5/9-dc23

LC record available at https://lccn.loc.gov/2019007532

A British Cataloging-in-Publication record for this book is available from the British Library.

Copyright $(2020$ by Paul Williams

All rights reserved

No part of this book may be reproduced or utilized in any form or by any means, electronic or mechanical, or by any information storage and retrieval system, without written permission from the publisher. Please contact Rutgers University Press, 106 Somerset Street, New Brunswick, NJ $\circ 890$. The only exception to this prohibition is "fair use" as defined by U.S. copyright law.

(0) The paper used in this publication meets the requirements of the American National Standard for Information Sciences-Permanence of Paper for Printed Library Materials, ANSI

Z39.48-1992.

www.rutgersuniversitypress.org

Manufactured in the United States of America 
History makes itself in such a way that the final result always arises from conflicts between many individual wills, of which each again has been made what it is by a host of particular conditions of life. Thus there are innumerable intersecting forces, an infinite series of parallelograms of forces, which give rise to one resultant-the historical event. This again may be viewed as the product of a power which, taken as a whole, works unconsciously and without volition. For what each individual wills is obstructed by everyone else, and what emerges is something no one willed.

-Letter from Frederick Engels to J. Bloch, September 2I, I890 

For Helen 
